\title{
Prevalence and Risk Factors for Toxoplasmosis in Middle Java, Indonesia
}

\author{
Annisa Retmanasari, ${ }^{1,5}$ Barandi Sapta Widartono, ${ }^{2}$ Mahardika Agus Wijayanti, ${ }^{3}$ \\ and Wayan Tunas Artama ${ }^{4,5}$ \\ ${ }^{1}$ Postgraduate Program of Tropical Medicine, Faculty of Medicine, Universitas Gadjah Mada, Yogyakarta, Indonesia \\ ${ }^{2}$ Departement of GISRP, Faculty of Geography, Universitas Gadjah Mada, Yogyakarta, Indonesia \\ ${ }^{3}$ Faculty of Medicine, Universitas Gadjah Mada, Yogyakarta, Indonesia \\ ${ }^{4}$ Departement of Biochemistry, Medical Veterinary Faculty, Universitas Gadjah Mada, Jl. Fauna 2 Karangmalang, Yogyakarta 55281, Indonesia \\ ${ }^{5}$ EcoHealth Resource Center (EHRC)-Universitas Gadjah Mada, Yogyakarta, Indonesia
}

\begin{abstract}
Toxoplasmosis is a zoonosis caused by Toxoplasma gondii. Risk factors include consumption of undercooked meat, raw vegetables, and unfiltered water. This study aims to determine the seroprevalence and spatial distribution of toxoplasmosis in Middle Java, Indonesia, using an EcoHealth approach, combined with geographic information system (GIS). A total of 630 participants were randomly selected from seven districts. Each participant completed a questionnaire and provided a blood sample. The seroprevalence of toxoplasmosis was $62.5 \%$. Of those who were seropositive, $90.1 \%$ were IgG+, and 9.9\% were IgG+ and IgM+. Several risk factors were identified, including living at elevations of $\leq 200 \mathrm{~m}$, compared with $>200 \mathrm{~m}(\mathrm{OR}=56.2$; $P<0.001)$, daily contact with raw meat $(\mathrm{OR}=1.8 ; P=0.001)$, unfiltered water $(\mathrm{OR}=1.7 ; P=0.003)$, and density of cats $(\mathrm{OR}=1.4 ; P=0.045)$. Visualizing the spatial distribution of seropositive respondents highlighted clustering in lowland areas. This study highlighted that Middle Java has a high prevalence of toxoplasmosis and identified some important environmental, ecological, and demographic risk factors. When researching diseases, such as toxoplasmosis, where animal hosts, human lifestyle, and environmental factors are involved in transmission, an EcoHealth method is essential to ensure a fully collaborative approach to developing interventions to reduce the risk of transmission in high-risk populations.
\end{abstract}

Keywords: toxoplasmosis, seroprevalence, risk factors, geographic information system (GIS), EcoHealth

\section{IntRoduction AND Purpose}

Toxoplasmosis, a zoonotic disease prevalent worldwide, is caused by the protozoan parasite Toxoplasma gondii ( $T$. gondii). The lifecycle of this parasite has three stages: the oocyst, bradyzoite (cyst), and tachyzoite. Tachyzoites ac-

Published online: November 9, 2016

Correspondence to: Wayan Tunas Artama, e-mail: artama@ugm.ac.id tively and rapidly invade hosts cells, aided by one of the most prevalent proteins: Granule-1 (GRA-1). This protein is responsible for binding with the calcium released into the lumen of the vacuole and interacting with tissue (Weis and Kami 1995; Lee et al. 2014). Toxoplasmosis can lead to congenital malformation in the intermediate host, abortion, and hydrocephalus (Fusco et al. 2007; Tavassoli et al. 2013).

Worldwide, over 6 billion people have been infected with toxoplasmosis (Klaren and Kijlsstra 2002). The sero- 
prevalence of toxoplasmosis in humans varies in different countries, with previous studies reporting country-specific prevalence rates of $6.7 \%$ in Korea; $12.3 \%$ in China; $23.9 \%$ in Nigeria; $46.0 \%$ in Tanzania, and high prevalence of up to 98.0\% in some regions (Glasner et al. 1992; Fromont et al. 2009; Kamani et al. 2009; Shin et al. 2009; Swai and Schoonman 2009; and Xiao et al. 2010). Serological studies in livestock revealed that worldwide the average $T$. gondii prevalence is $14.0 \%$ in cattle; $27.0 \%$ in goats; $25.0 \%$ in pigs; $66.0 \%$ in sheep; and $44.0 \%$ in horses (Tenter et al. 2000). In Indonesia, the prevalence of toxoplasmosis in livestock has been estimated as $8.8 \%$ in cattle, $51.0 \%$ in goats, and $45.0 \%$ in sheep (Artama et al. 2007). The prevalence of human toxoplasmosis in Indonesia for humans has been reported from 43 to $88 \%$ in some regions (Subekti et al. 2006).

Transmission of toxoplasmosis can occur through two mechanisms: vertically from mother to fetus and horizontally through the consumption of undercooked meat, contaminated milk, and raw vegetables, and also in the case of transplants and accidents in laboratory (Fusco et al. 2007; Gangneux and Marie, 2012; Uttah et al. 2013; and Wing 2016). Members of the family Felidae (domestic cats) are the definitive hosts; however, many mammals (live stocks and humans), birds, and fishes are intermediate hosts (Gilot-Fromont et al. 2012; Webster et al. 2013). A single cat can shed more than 100 million oocysts in prepatent period about 18 days. In order for these oocysts to become infectious, they must undergo sporulation, which can take more than 4 days and occurs in environments with high humidity and a low temperature. Oocysts can survive outdoors for many months, remain viable for long periods of time in water, and resist freezing and moderately high water temperatures. Tissue cysts in meat are usually destroyed by heating to $67^{\circ} \mathrm{C}$. The survival of tissue cysts at lower temperatures depends on the duration of cooking (Tenter et al. 2000).

Country-specific environmental conditions, eating habits, hygiene, and host susceptibility all contribute to global differences in the prevalence of toxoplasmosis (Furtado et al. 2011). Indonesia has a tropical climate, providing suitable conditions for gardening and farming, increasing human contact with soil and livestock, as well as the possibility of increasing contact with raw meat. Additionally, it is common to consume goat, sheep, beef, chicken, and rabbit satay, potentially with undercooked meat and raw vegetables. In a multicenter study in Europe, meat consumption was estimated to be responsible for between 30.0 and $63.0 \%$ of toxoplasmosis cases, while soil contact was identified as the cause of between 6.0 and $17.0 \%$ of cases (Gangneux and Marie 2012).

Health and disease are increasingly understood as the product of interrelated ecological, cultural, social, and economic situations (Blazkuez et al. 2014). Socio-demographic status, lifestyle, and environment are risk factors for toxoplasmosis; therefore, interdisciplinary collaborative research is essential to reduce the risk of transmission. EcoHealth is one of several integrative approaches that considers interactions between health and the environment, making it an ideal approach for researching a zoonosis such as toxoplasmosis.

Previous research on toxoplasmosis has identified high-risk geographical areas; however, further investigation using spatial techniques will achieve more accurate identification of high-risk locations, which can be used to improve strategies to prevent the spread of this disease. Geographic Information Systems (GIS) have been applied in several situations, including surveillance and monitoring of diseases (Jores et al. 2008), disease cluster detection (Miller et al. 2004), identification of environmental predictors of disease in wildlife populations (Miller et al. 2002), risk assessments (Hung et al. 2004, 2007), and modeling the spread and impact of disease (Norman 2008). In the present study, the use of GIS, combined with a seroprevalence study and risk factor questionnaire, demonstrates a true EcoHealth approach, which is essential when researching diseases, such as toxoplasmosis, where animal hosts, human lifestyle, and environmental factors are all involved in transmission. The use of GIS will aid in the identification of high-risk locations, enabling public health interventions to be targeted at specific populations in Middle Java. This system was constructed utilizing the administrative boundaries (at provincial and municipal levels) of the Campania region with toxoplasmosis cases (Fusco et al. 2007).

Using an EcoHealth approach, this study aims to determine the seroprevalence and spatial distribution of toxoplasmosis in Middle Java, and identify factors associated with the occurrence of toxoplasmosis.

\section{Methods}

\section{Setting and Design}

A cross-sectional study was conducted in 2014 in seven districts in Middle Java that were divided into three clusters: Cluster 1 (Purworejo and Kebumen); Cluster 2 
(Cilacap and Banyumas); and Cluster 3 (Purbalingga, Banjarnegara and Wonosobo). The distribution of the sample was determined based on geographical location and topography of the region. The districts were chosen to be representative of the Middle Java region. The required sample size was calculated to be 588 with $10 \%$ non-response rate; a rounded-up sample size of 630 respondents recruited. It was calculated using proportional sample size as follows:

$$
\text { Sample size }=\frac{Z_{1-\alpha / 2^{2}} p(1-p)}{d^{2}}
$$

Here $Z_{1-\alpha / 2}$ is the Standard normal variation [at $5 \%$ type error $(P<0.05)], P$ is Expected proportion in population based on previous studies or pilot studies, and $\mathrm{d}$ is the Absolute error or precision (has to be decided by researcher)

(Charan and Tamoghna 2013)

According to previously published studies, using a toxoplasmosis estimate of $15 \%$ and assuming a $95 \%$ confidence interval, sampling was performed using a multistage cluster sampling method. In the first stage, the selection of the research clusters (districts) and sub-clusters (subdistrict, village, and subvillage) was performed based on probability proportionate to size (PPS). In the second stage, households were randomly selected in each district using a simple random sampling technique (Rosen 1997; United Nations 2005). Participants were approached by the community leader and research team, and they were asked if they wanted to participate in the study. Informed consent was sought from all participants prior to enrolment in the study. Blood samples were collected from participants by venipuncture using sterile syringes and transferred into serum separator tubes. The tubes were labeled and transported to the laboratory in thermic bags at $2-8^{\circ} \mathrm{C}$.

\section{Survey Design}

In addition, a questionnaire was completed by all respondents that included demographics, diet (consumption of undercooked meat, raw vegetables, and raw water), daily activity (interaction with cats, contact with raw meat, and daily contact with soil), and local environment (water resource, temperature, elevation, distance from river, humidity, and population of cats). The cat population in square kilometer was considered to be of lower density if the population was less than 15 , and higher density if the population was more than 15 .

\section{Serum Collection and Testing}

A sample of up to $3 \mathrm{cc}$ of blood was obtained from each participant. Blood samples were stored overnight in the refrigerator at $4^{\circ} \mathrm{C}$. The serum was separated from the blood and transferred to eppendorf tubes to measure $\operatorname{IgM}$ and IgG. Serum was stored in a freezer at $-20^{\circ} \mathrm{C}$. Serum samples were screened for $T$. gondii using an indirect ELISA (Rahbari et al. 2012), using the recombinant GRA-1 tachyzoite antigen (Sulistyaningsih et al. 2005).

\section{Spatial Data Collection}

GIS software (ArcGIS 10.1) produced by ESRI was used to map the spatial distribution of $T$. gondii. The administrative map was provided by the Center for Research, Promotion and Cooperation Geospatial Information Agency (http://www.bakosurtanal.go.id/peta-rupabumi/); the watershed map was provided by the Center for Data Processing Ministry of Public Works and Public Housings (http://sigi.pu.go.id/); and the topography map was provided by the United States Geological Survey (.srtm format). The household's distance from the river was collected from interview data and generated using Google Earth produced by Google. Environmental data, such as temperature, were collected using digital readings in field. Spatial distribution was visualized using overlay (ESRI 2001), which combines digital maps with attribute data.

\section{Statistical Analysis}

A chi-square test (bivariate test) from SPSS Statistic 22 produced by IBM was used to determine factors associated with the seroprevalence of $T$. gondii. Statistical significance was set at a value of $P<0.05$.

\section{Results}

\section{Seroprevalence of Toxoplasmosis in Middle Java}

All participants were notified prior to the household visit and only one respondent (between the ages of 15-60) per household was interviewed and asked to provide a blood sample. A total of 630 samples were collected from the surveyed households in Middle Java. The results identified the prevalence of toxoplasmosis was $(n=394 ; 62.5 \%)$ (Table 1$)$. Thirty-nine respondents $(9.9 \%)$ were seroposi- 
Table 1. Seroprevalence of Toxoplasmosis Based on IgG and IgM Anti-toxoplasma Examination by ELISA Using GRA-1 Tachyzoite Local Isolate Recombinant Proteins of T. gondii in Middle Java, 2014.

\begin{tabular}{lll}
\hline Toxoplasmosis & All respondents $n$ & Percentage (\%) \\
\hline Positive $(n=630)$ & 394 & 62.54 \\
Negative $(n=630)$ & 236 & 37.46 \\
\hline
\end{tabular}

Table 2. Results of IgG and IgM Anti-toxoplasma Examination in Middle Java, 2014.

\begin{tabular}{lcc}
\hline Category & All respondents $n$ & $\begin{array}{l}\text { Percentage } \\
(\%)\end{array}$ \\
\hline $\operatorname{IgG}(+)$ and $\operatorname{IgM}(+)(n=630)$ & 39 & 9.89 \\
$\operatorname{IgG}(+)$ and $\operatorname{IgM}(-)(n=630)$ & 355 & 90.10 \\
\hline
\end{tabular}

tive for $\operatorname{IgG}$ and $\operatorname{IgM}$, with the remaining respondents ( $n=355 / 394 ; 90.1 \%$ ) being seropositive for IgG (Table 2).

\section{Risk Factors for Toxoplasmosis in Middle Java}

Several risk factors for toxoplasmosis in Middle Java were identified (Table 3). The greatest risk was presented by an elevation at or under $200 \mathrm{~m}$, compared with an elevation over $200 \mathrm{~m}(\mathrm{CI}=27.65-114.23$; $\mathrm{OR}=56.19 ; P<0.001)$. Respondents whose daily work or other activities included direct contact with raw meat were at increased risk compared with those who did not have regular contact with raw meat $(\mathrm{CI}=1.27-2.47 ; \mathrm{OR}=1.77 ; P=0.001)$. The risk of toxoplasmosis was also higher for respondents who did not filter their water $(\mathrm{CI}=1.22-2.49 ; \mathrm{OR}=1.74 ; P=0.003)$, and for those who lived in an area with a high population of cats $(\mathrm{CI}=1.02-1.98 ; \mathrm{OR}=1.42 ; P=0.045)$.

Risk factors for toxoplasmosis varied depending on geographical location; each district presented different risks (Fig. 1; Table 4). The districts at a higher elevation, Wonosobo and Banjarnegara, had no cases of toxoplasmosis (Fig. 2). Purworejo, Kebumen, Banyumas, Purbalingga, Banjarnegara, and Wonosobo districts had the highest proportion of respondents who did not use filtered water, ranging from $91.4 \%$ in Kebumen to $55.7 \%$ in Purbalingga (Table 4). The highest proportion of respondents who reported the population of cats in their district was high are Purworejo (58.6\%) and Kebumen (52.9\%). Purworejo, Kebumen, Banyumas, Purbalingga, and Wonosobo districts reported as the largest proportions of respondents with high rates of contact with raw meat during their daily work or other activities, ranging from $75.0 \%$ in Kebumen to $57.1 \%$ in Purbalingga (Table 4). Additionally, 570 respondents $(90.5 \%)$ did not use gloves when handling raw meat.

\section{Spatial Distribution of Toxoplasmosis in Middle Java}

The spatial distribution of toxoplasmosis combined with elevation is illustrated in Fig. 1 and with the watershed in Fig. 2. The lowland districts of Purworejo, Kebumen, and Banyumas had predominantly chronic toxoplasmosis infections, $\operatorname{IgG}(+)$ and $\operatorname{IgM}(-)$, illustrated in yellow on the map. Recent infection with toxoplasmosis, (IgG $(+)$ and IgM $(+)$, is represented by red (Figs. 1, 2). Cilacap (a lowland district) and Purbalingga (a highland district) had predominantly chronic infections or negative samples, IgG (-) and IgM (-), shown in green. Districts with no positive samples, Banjarnegara and Wonosobo, are located in mountainous or hilly locations, over $500 \mathrm{~m}$.

This study was conducted in the watershed regions of Serayu, Tipar, Lukulo, and Bogowonto (Fig. 2). Tipar, Lukulo, and Bogowonto have a similar seroprevalence of toxoplasmosis. Within the Serayu watershed, there were two distinct groups of cases, with no cases upstream of Serayu (Wonosobo and Banjarnegara districts). Cases of toxoplasmosis were identified in Purbalingga and downstream from the river in Cilacap.

\section{DISCUSSION}

In this study, the prevalence of toxoplasmosis was greater in the lowlands as compared with the highland districts of Middle Java, Indonesia. One possible explanation could be the contamination of water sources from drifting soil, in the event of flooding or heavy rain, transporting oocysts from high to low ground, thus increasing the prevalence of oocysts in low-lying areas (Iskandar 1999).

Wonosobo and Banjarnegara had no cases of toxoplasmosis in this study. These are highland districts, with mountainous terrain, which may also affect the distribution of cats. As the cat is the definitive host of T. gondii, (Tavassoli et al. 2013), fewer cats in the environment will reduce the risk of transmission to the environment and 
Table 3. Risk Factors for Toxoplasmosis in a Sample of 630 People in Middle Java, 2014.

\begin{tabular}{|c|c|c|c|}
\hline Variable & Prevalence $n(\%)$ & OR (95\% CI) (Bivariate analysis) & $P$ value \\
\hline Sex & & $0.90(0.65-1.27)$ & $0.023^{*}$ \\
\hline Women $(n=353)$ & $236(66.85)$ & & \\
\hline Men $(n=247)$ & $158(63.97)$ & & \\
\hline Interaction with cats & & $0.72(0.50-1.03)$ & 0.092 \\
\hline Yes $(n=438)$ & $264(60.27)$ & & \\
\hline Never $(n=192)$ & $130(67.71)$ & & \\
\hline Density of cat & & $1.42(1.02-1.98)^{\star}$ & $0.045^{\star}$ \\
\hline High $(n=263)$ & $177(67.30)$ & & \\
\hline Low $(n=367)$ & $217(59.12)$ & & \\
\hline Consumption of undercooked meat & & $0.85(0.62-1.18)$ & 0.386 \\
\hline Yes $(n=329)$ & $200(60.79)$ & & \\
\hline Never $(n=301)$ & $194(64.45)$ & & \\
\hline Consumption of raw vegetables & & $0.41(0.09-1.96)$ & 0.412 \\
\hline Yes $(n=580)$ & $386(66.55)$ & & \\
\hline Never $(n=50)$ & $8(16.00)$ & & \\
\hline Contact with raw meat & & $1.77(1.27-2.46)^{\star}$ & $0.001^{\star}$ \\
\hline Yes $(n=385)$ & $261(67.80)$ & & \\
\hline No $(n=245)$ & $133(54.28)$ & & \\
\hline Consumed raw water & & $0.73(0.51-1.04)$ & 0.098 \\
\hline Yes $(n=180)$ & $103(57.22)$ & & \\
\hline No $(n=450)$ & $291(64.67)$ & & \\
\hline Water resource & & $1.74(1.22-2.48)^{*}$ & $0.003^{\star}$ \\
\hline Without filtration $(n=458)$ & $303(66.16)$ & & \\
\hline With filtration $(n=172)$ & $91(52.91)$ & & \\
\hline Daily contact with soil & & $0.58(0.30-1.12)$ & 0.136 \\
\hline Yes $(n=580)$ & $358(61.72)$ & & \\
\hline No $(n=50)$ & $36(72)$ & & \\
\hline Temperature & & $0.57(0.41-0.81)$ & $0.002^{*}$ \\
\hline$<29^{\circ} \mathrm{C}(n=192)$ & $103(53.65)$ & & \\
\hline$\geq 29^{\circ} \mathrm{C}(n=437)$ & $291(66.59)$ & & \\
\hline Elevation & & $56.19(27.65-114.23)^{\star}$ & $0.000^{*}$ \\
\hline$\leq 200 \mathrm{~m}(n=487)$ & $385(79.05)$ & & \\
\hline$>200 \mathrm{~m}(n=143)$ & $9(6.29)$ & & \\
\hline Distance from river & & $0.27(0.13-0.56)$ & $0.000^{*}$ \\
\hline$\leq 500 \mathrm{~m}(n=336)$ & $236(70.24)$ & & \\
\hline$>500 \mathrm{~m}(n=52)$ & $42(80.77)$ & & \\
\hline Humidity & & $0.69(0.36-1.32)$ & 0.330 \\
\hline$<60 \%(n=47)$ & $33(70.21)$ & & \\
\hline$>60 \%(n=583)$ & $361(61.92)$ & & \\
\hline
\end{tabular}

$\star$ Significant with $P$ value $<0.05$.

livestock, thereby reducing the prevalence of toxoplasmosis in the local population.

Daily contact with raw meat was also identified as a risk factor for toxoplasmosis. Toxoplasmosis can occur during the transmission of $T$. gondii via the blood through a wound
(CCOHS 2011). Daily contact with raw meat from infected animals increases the possibility of contact with tissue cysts, particularly if no protective equipment, such as gloves, is worn. Additionally, tissue cysts may be ingested during handto-mouth contact after handling undercooked meat, or from 


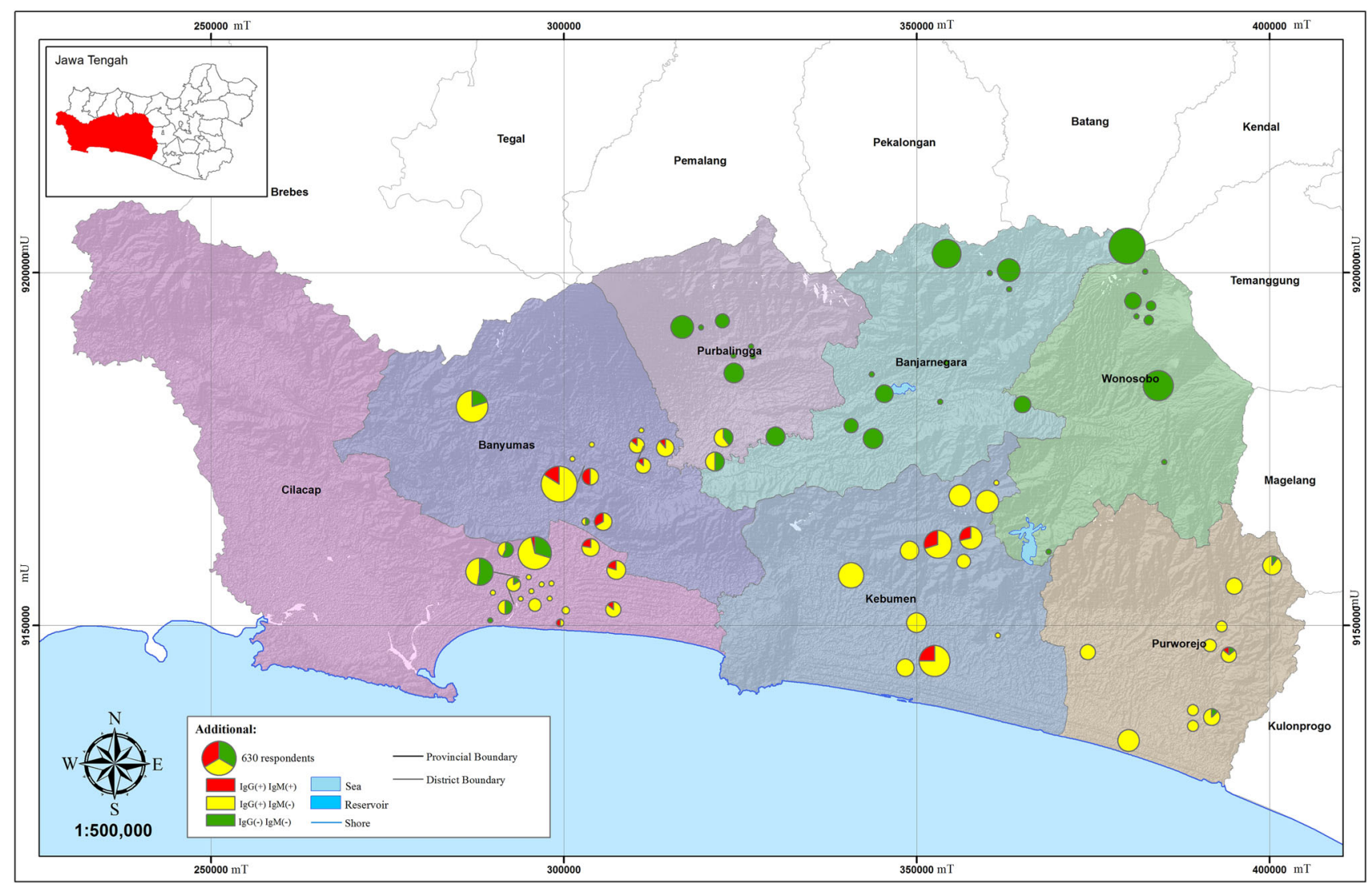

Figure 1. Spatial distribution of toxoplasmosis based on administration boundaries in Middle Java, Indonesia 2014.

using knives, utensils, or cutting boards contaminated by raw meat (CDC 2004). This will also increase the risk of transmission in people who have regular contact with raw meat.

Consumption of unfiltered water was also identified as a risk factor for toxoplasmosis. Respondents who used nonfiltered water were at increased risk of toxoplasmosis compared with those using a filtered water source. Consumption of unfiltered water was associated with water sources such as rivers, wells, and reservoirs. Oocysts can be transported via rivers and water during periods of heavy rain. Water is not just used for human consumption, but also for washing vegetables and as drinking water for livestock. The majority of respondents in Cilacap used filtered water. Cilacap is near the coast and because of the potential seawater contamination of water sources in this district, the use of filtered water is more widespread compared with other districts in Middle Java. This may be one factor leading to minimal cases of toxoplasmosis in several locations in Cilacap. Water is filtered using chlorine to reduce bacteria and parasites. Oocysts cannot survive for long in cold water conditions or in warm water with high levels of chlorination, UV, and ozone treatment (Wainwraight et al. 2007; Gangneux and Marie 2012).

This study identified a relationship between the population of cats and toxoplasmosis cases; people living in districts with high density of cats, Purworejo and Kebumen, were at increased risk of toxoplasmosis compared with those living in districts with low density of cats. Middle Java in general has a relatively small cat population, which varies in each district. A small number of cats do not necessarily indicate there is no risk of infection in that location. Cat feces take a long time to decay (Gangneux and Marie 2012), and during that time thousands of oocysts can develop (Ishaku et al. 2009).

In the surveyed population, men were at increased risk of infection compared with women. This could be associated with the differing roles of men and women in Middle Java; male-dominated professions, such as farming and meat production, will increase the risk of contact with contaminated meat, as well as increasing the risk of environmental exposure through spending long periods of time outdoors or in high-risk areas. 
Table 4. Percentage of Toxoplasmosis Risk Factors in Each District of Middle Java.

\begin{tabular}{|c|c|c|c|c|c|c|}
\hline \multirow[t]{3}{*}{ District } & \multicolumn{6}{|l|}{ Risk factors (\%) } \\
\hline & \multicolumn{2}{|l|}{ Water sources } & \multicolumn{2}{|c|}{ Population of cats } & \multicolumn{2}{|c|}{ Contact with raw meat } \\
\hline & Without filtration & With filtration & Many & Few & In work & Not in work \\
\hline Purworejo & 82.86 & 17.14 & 58.57 & 41.43 & 70.00 & 30.00 \\
\hline Kebumen & 91.43 & 8.57 & 52.86 & 47.14 & 75.00 & 25.00 \\
\hline Cilacap & 47.72 & 52.78 & 29.03 & 70.37 & 47.22 & 52.78 \\
\hline Banyumas & 65.69 & 34.31 & 31.32 & 68.63 & 65.69 & 34.31 \\
\hline Purbalingga & 55.71 & 44.29 & 48.57 & 51.43 & 57.14 & 42.86 \\
\hline Banjarnegara & 85.74 & 14.26 & 34.29 & 65.71 & 47.14 & 52.86 \\
\hline Wonosobo & 78.57 & 21.43 & 37.14 & 62.86 & 57.14 & 42.86 \\
\hline
\end{tabular}

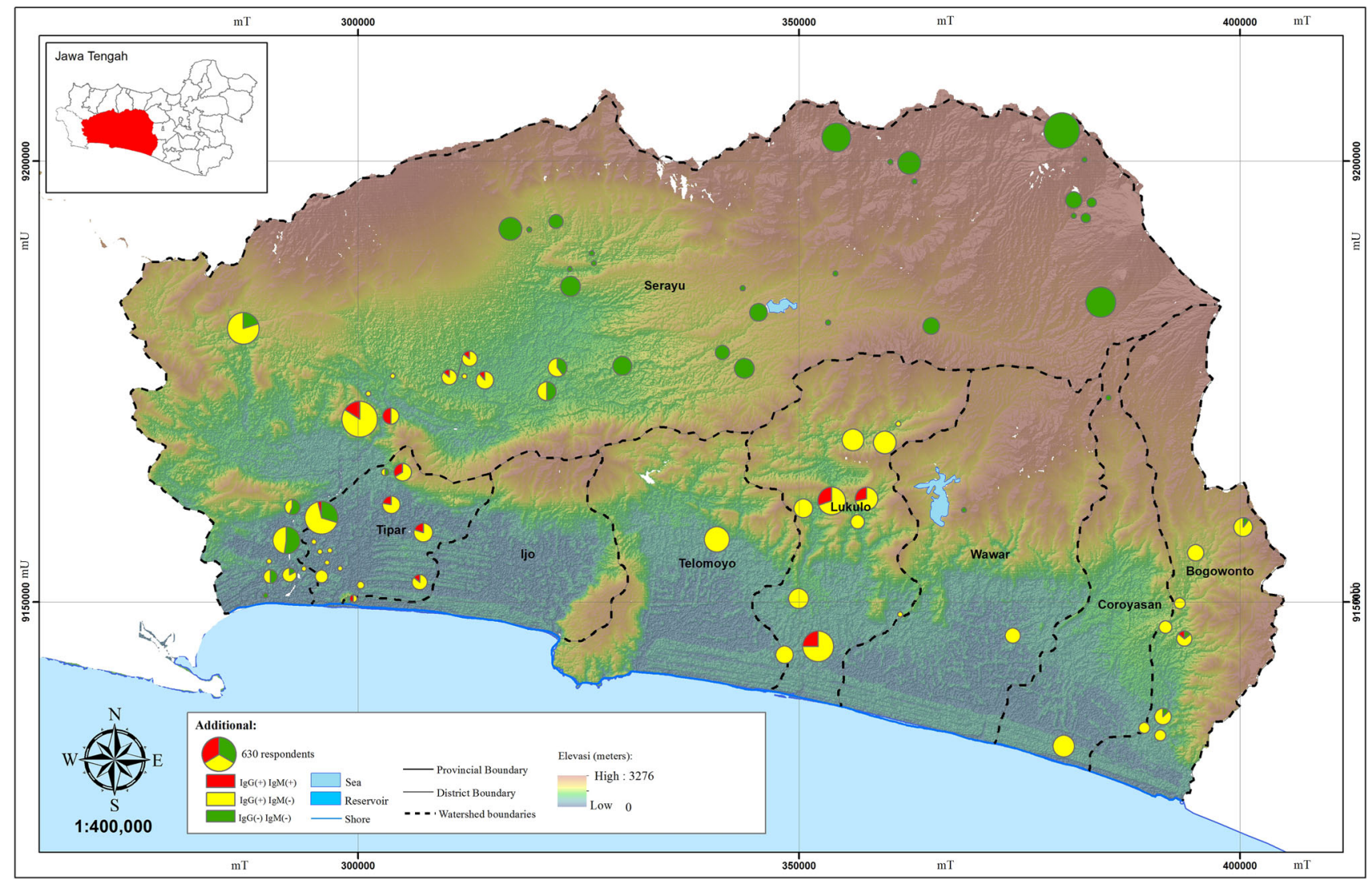

Figure 2. Correlation of toxoplasmosis with elevation on watershed's Middle Java, Indonesia 2014.

\section{CONCLUSION}

This study highlighted the high prevalence of toxoplasmosis in Middle Java, and identified some important environmental, ecological, and demographic risk factors. Low elevation, contact with raw meat, unfiltered water sources, and the high density of cats are supposed to be risk factors of toxoplasmosis in Middle Java. Modifiable risk factors, such as unfiltered water sources and direct contact with raw meat, are relatively straightforward to address by encouraging people to use filtered water and wear protective clothing, such as gloves, when handling raw meat. The oocyst from infected cats will be transmitted to the environment through water shed and 
flooding and distributed from high land to low-lying areas.

\section{ACKNOWLEDGEMENTS}

The authors are sincerely grateful to Mr. Sudjono and his students for helping in collecting samples from respondents. The authors are grateful for support from Program Direktoral Jendral Pendidikan Tinggi in 2014 number 225/ LPPM/2014-2015 and EcoHealth Resource Center (EHRC) for advice.

\section{COMPLIANCE WITH ETHICAL STANDARDS}

ETHICAL APPROVAL Ethical approval was obtained from the Medical and Health Research Ethics Committee (MHREC), Faculty of Medicine, Universitas Gadjah Mada. All information collected from patient records were kept strictly confidential.

INFORMED CONSENT Informed consent was obtained from all individual participants included in the study. The informed consent process included explaining all procedures in this research were safe and describing all risks and benefits of the process.

\section{OPEn ACcess}

This article is distributed under the terms of the Creative Commons Attribution 4.0 International License (http:// creativecommons.org/licenses/by/4.0/), which permits unrestricted use, distribution, and reproduction in any medium, provided you give appropriate credit to the original author(s) and the source, provide a link to the Creative Commons license, and indicate if changes were made.

\section{REFERENCES}

Artama WT, Iskandar T, Widayanti R, Haryanto A (2007) Kloning, ekspresi gen penyandi protein excretory secretory antigen (esas) dan aplikasi protein rekombinan untuk menentukan prevalensi toksoplasmosis pada sapi, kambing dan domba di indonesia. http://www.litbang.pertanian.go.id/ks/one/406/ file/kloning-ekspresi-gen-penya.pdf. Accessed Aug 25, 2015

Behnke MS, Tiange PZ, Jitender PD, David S (2014) Toxoplasma gondii merozoit gene expression analysis with comparison to the life cycle discloses a unique expression state during enteric development. Biomed Central Genomics 15:1-17
Canadian Centre for Occupational Health and Safety (2011) Toxoplasmosis. https://www.ccohs.ca/oshanswers/diseases/tox oplasmosis.html. Accessed Aug 30, 2016

Centers for Disease Control and Prevention (2004) Toxoplasmosis. http://www.cdc.gov/parasites/toxoplasmosis/epi.html. Accessed Aug 25, 2015

Charan J, Tamoghna B (2013) How to calculate sample size for different study designs in medical research? Indian Journal of Psychological Medicine 35:121-126

Davis JT (2012) The application of GIS and spatiotemporal analyses to investigations of unusual marine mammal strandings and mortality events. Marine Mammal Science 28:E251E266

ESRI (2001) Spatial analysis: Advanced GIS spatial analysis using raster and vector data. https://www.esri.com/library/white papers/pdfs/arcgisspatialanalyst.pdf. Accessed March 24, 2014

Fromont EG, Riche B, Rabilloud M (2009) Toxoplasma seroprevalence in a rural population in France: Detection of a household effect. BMC Infectious Diseases 9:76

Fusco G, Rinaldi L, Guarino A, Proroga YTR, Pesce A, Giuseppina DM, Cringoli G (2007) Toxoplasma gondii in sheep from Campania region (Italy). Veterinary Parasitology 149:271-274

Gangneux RF, Marie LD (2012) Epidemiology of and diagnostic strategies for toxoplasmosis. Clinical Microbiology Reviews $25: 264$

Gilot-Fromont E, Maud L, Marie-Laure D, Céline R, Dominique A, Eve A, Aurélien M, Cécile G, Isabelle V (2012) The life cycle of Toxoplasma gondii in the natural environment. http://www. intechopen.com/books/toxoplasmosis-recent-advances/the-lifecycle-of-toxoplasma-gondii-in-the-natural-environment. Accessed Aug 30, 2016

Glasner PD, Silveira C, Kruszon-Moran D, Martins MC, Burnier JM, Silveira S, Camargo ME, Nussenblatt RB, Kaslow RA, Belfort JR (1992) An unusually high prevalence of ocular toxoplasmosis in Southern Brazil. American Journal of Ophthalmology 114:136-144

Hung CLH, So MK, Connell DW, Fung CN, Lam MHW, Nicholson S, Richardson BJ, Lam PKS (2004) A preliminary risk assessment of trace elements accumulated in fish to the IndoPacific humpback dolphin (Sousa chinensis) in the northwestern waters of Hong Kong. Chemosphere 56:643-651

Hung CLH, Lau RK, Lam JC (2007) Risk assessment of trace elements in the stomach contents of Indo-Pacific humpback dolphins and finless porpoises in Hong Kong waters. Chemosphere 66:1175-1182

Ishaku BS, Ajogi I, Umoh JU, Lawal I, Randawa AJ (2009) Seroprevalence and risk factors for Toxoplasma gondii infection among antenatal women in Zaria, Nigeria. Research Journal of Medicine \& Medical Science 4:438-488

Iskandar T (1999) Tinjauan tentang toxoplasmosis pada hewan dan manusia. Wartazoa 8:58-63

João MF, Justine RS, Kevin LW (2011) Toxoplasmosis: A global threat. Journal Global infectious diseases 3:281-284

Jores JAE, Derocher AE, Staubach C, Aschfalk A (2008) Occurrence and prevalence of Clostridium perfringens in polar bears from Svalbard, Norway. Journal of Wildlife Diseases 44:155-158

Kamani J, Mani AU, Egwu GO, Kumshe HA (2009) Seroprevalence of human infection with Toxoplasma gondii and the associated risk factors, in Maiduguri, Borno state, Nigeria. Annals of Tropical Medicine Parasitology 103:317-321 
Katlyn EW, Melissa AM, Bradd CB, Ian AG, Ann CM, Tim E, Andrea EP, Tin T, Manuel LS, Patricia AC (2007) Chemical inactivation of Toxopasma gondii oocysts in water. Journal of Parasitology 93:925-931

Miller MA, Gardner IA, Kreuder C, Paradies DM, Worcester KR, Jessup DA, Dodd E, Harris MD, Ames JA, Packham AE, Conrad PA (2002) Coastal freshwater runoff is a risk factor for Toxoplasma gondii infection of southern sea otters (Enhydra lutris nereis). International Journal for Parasitology 32:997-1006

Miller MA, Grigg ME, Kreuder C, James ER, Melli AC, Crosbie PR, Jessup DA, Boothroyd JC, Brownstein D, Conrad PA (2004) An unusual genotype of Toxoplasma gondii is common in California sea otters (Enhydra lutris nereis) and is a cause of mortality. International Journal for Parasitology 34:275-284

Lee W, Hye-Jin A, Je-Hyun B, Chong-Heon L, Yeon GY, Ho-Woo $\mathrm{N}$ (2014) Comprehensive proteome analysis of the excretory/ secretory proteins of Toxoplasma gondii. Bulletin of the Korean Chemical Society 35:3071-3076

Rahbari AH, Kesharvaz H, Schojae S, Mohebale M, Rezaeian M (2012) IgG avidity ELISA test for diagnosis of acute toxoplasmosis in humans. Korean Journal Parasitology 50:99-102

Rosen B (1997) On sampling with probability proportional to size. Journal of Statistical Planning and Inference 62:159-191

Shin DW, Cha DY, Hua QJ, Cha GH, Lee YH (2009) Seroprevalence of Toxoplasma gondii infection and characteristics of seropositive patients in general hospitals in Daejeon, Korea. Korean Journal Parasitology 47:125-130

Simon A, Michel BP, Alain NR, Nicholas HO (2013) Fate and transport of Toxoplasma gondii oocysts in seasonally snow covered watersheds: A conceptual framework from a melting snowpack to the Canadian Arctic Coasts. International Journal Environmental Research Public Health 10:994-1005

Sulistyaningsih E, Moeljopawiro S, Subandono J, Artama WT (2005) Cloning of cDNA encoding GRAl protein of tachyzoite Toxoplasma gondii local isolate. Indonesia Journal of Biotechnology 10:763-767

Suyatno (2013) Menghitung besar sampel penelitian kesehatan masyarakat. Fakultas Kesehatan Masyarakat UNDIP Semarang. http://www.slideshare.net/tobrono/menghitungbesarsampelpe nelitian. Accessed March 24, 2014
Swai ES, Schoonman L (2009) Seroprevalence of Toxoplasma gondii infection amongst residents of Tanga district in northeast Tanzania. Tanzan Journal Health Research 11:205-209

Tamavo S (2014) Evolutionary repurposing of endosomal systems for apical organelle biogenesis in Toxoplasma gondii. International Journal for Parasitology 44:133-138

Tavassoli M, Ghorbanzadehghan M, Esmaellnejad B (2013) Detection of Toxoplasma gondii in sheep and goats blood samples by PCR-RFLP in Urmia. Veterinary Research Forum 4:43-47

Tenter AM, Heckeroth AR, Weiss LM (2000) Toxoplasma gondii: from animals to humans. International Journal Parasitology 30:1217-1258

Uttah E, Emmanuel O, Christiana O (2013) Toxoplasmosis: A global infection, so widespread, so neglected. International Journal of Scientific and Research Publication 3:2250-3153

United Nations (2005) Designing household survey samples: practical guidelines. http://unstats.un.org/unsd/demographic/ sources/surveys/Handbook23June05.pdf. Accessed March 24, 2014

Wang Y, Yin H (2014) Research progress on surface antigen 1 (SAG1) of Toxoplasma gondii. Parasites and Vectors 7:1-9

Webster JP, Maya K, Greg CB, Glenn AM (2013) Toxoplasma gondii infection, from predation to schizophrenia: Can animal behaviour help us understand human behaviour? Journal of Experimental Biology 216:99-112

Weis LM, Kami K (2014) Toxoplasma gondii The model of Apicomplexan: Perspective Methods, 2nd ed., San Diego: Academic Press, pp 439

West MD (2008) Use of the Chi-square statistic. http://ocw.jhsph. edu/courses/fundepiii/pdfs/lecture17.pdf. Accessed March 24, 2014

Wing EJ (2016) Toxoplasmosis: Cats have it, humans get It, but how much disease does it cause? Clinical Infectious Diseases 63:476-477

Xiao Y, Yin J, Jiang N, Xiang M, Hao L, Lu H (2010) Seroepidemiology of human Toxoplasma gondii infection in China. BMC Infectious Diseases 10:4 